\title{
The Open Method of Coordination as a 'two-level game'
}

Milena Büchs

Published in Policy \& Politics, 2008, Vol 36

This is NOT the final published version, please refer to DOI

$10.1332 / 030557308783431689$ for the published version.

\begin{abstract}
One of the most discussed issues surrounding the Open Method of Coordination is the way in which it 'influences' national social policies. This paper argues that the question of 'influence' is incorrectly posed. Instead, the Open Method of Coordination (OMC) has to be understood as a 'two-level game' in which member state governments and nongovernmental actors try to have an impact on the definition of the OMC objectives and, subsequently, strategically and selectively 'use' the OMC in national policy-making processes. This, however, entails problems in terms of the transparency of policy-making processes and accountability of national governments.
\end{abstract}

\section{Key Words}

Two-level game, Open Method of Coordination, European social policy, accountability

\section{Introduction}

The Open Method of Coordination (OMC) is a governance method which is 'softer' than the 'classical', 'regulatory' or 'redistributive' mode of EU governance (Wallace 2005). Its objectives are not legally binding and there are no formal sanctions available if member 
states fail to adopt or achieve OMC objectives. The OMC has been established as a 'middle way': on the one hand the EU becomes involved in formulating social policy objectives, whilst on the other, the member states' authority in social policy is still guaranteed, according to the principle of subsidiarity. Despite the fact that the $\mathrm{OMC}$ is not legally binding, the European Commission and Council, as well as many OMC scholars, assume that the OMC will be effective in achieving its objectives and that it will influence social policy-making at the national level. Therefore the paradoxical question of how a 'soft' and non-binding governance method could be effective arises. Why should member state governments 'implement' OMC objectives when they are not legally obliged to do so and are not threatened by sanctions other than 'naming and shaming' by the EU Commission, peer member states or experts? Are these 'soft sanctions' reason enough for introducing policy changes in line with the OMC?

Such questions regarding the OMC's 'influence' have been discussed in the OMC literature, within which there are predominantly two opposing views. Sceptical scholars compare the OMC to 'hard law' EU policies and argue that the OMC cannot influence national policy-making due to its non-bindingness and lack of sanctions (e.g. Chalmers and Lodge 2003: 13, 18f.). Optimistic OMC scholars, however, dispute this claim, arguing that 'hard law' is often not that 'hard' because it can contain very broad and abstract terms so that actors retain significant discretion when implementing it (e.g. Trubek and Trubek 2005). Furthermore, they assume that 'soft law' can be effective and in fact presents a more successful policy instrument than 'hard law', particularly if member states fundamentally disagree about policy approaches or want to retain authority in a particular policy area. This is the case with social policy.

In my view, the question of the OMC's influence cannot be answered with either a clear 'yes' or 'no'. Rather, the answer lies somewhere in the middle. Whilst the OMC makes a 
difference within national social policy development, it does not do so in the way promoted by the EU or hoped for by optimistic OMC scholars.

Moreover, it is not enough to examine the 'influence' of the OMC on national policymaking alone. This paper argues that the OMC is a variant of a 'two-level game' (Putnam 1988) in which member state governments and non-governmental actors can influence the OMC agenda at the EU level and, subsequently, strategically and selectively 'use' the OMC in national policy-making processes (cf also Jacquot and Woll 2003). The OMC 'two-level game' differs in some respects from Putnam's, as explained below. Overall, however, the OMC introduced a new mechanism for European social policy-making that poses new problems in terms of transparency, accountability and legitimacy.

Firstly, I will describe how the concept of OMC 'influence' has been applied so far in OMC research and point to some methodological problems involved with this approach. Subsequently, the theoretical explanations of the OMC's influence and effectiveness are briefly scrutinised. Here I argue that the currently available approaches already suggest that the OMC has to be interpreted as a 'two-level game', even if this has so far not been made sufficiently explicit. Then the policy-making processes at the EU and member state level are analysed to illustrate the two-level character of the OMC. Finally, the conclusion considers the consequences of this two-level game for the democratic quality of these soft multi-level policy-making processes.

\section{'Influence' in $\mathrm{OMC}$ research}

The EU presented the OMC as a means of strengthening 'social Europe' and the 'European Social Model' (European Council 2000b: 5; European Council 2000a: 15). Some authors even assume that the OMC could 'rebalance (...) the current structural asymmetry between negative and positive integration' (Ferrera and Rhodes 2000: 278). To achieve this, the OMC must be effective in the sense that it leads to the establishment of social policy objec- 
tives which are accepted in all member states and which then have an impact on social policy-making at the national level. Therefore questions regarding the OMC's effectiveness and influence dominate $\mathrm{OMC}$ evaluations and research. However, I claim that there are several flaws in the way in which this research is undertaken.

Available evaluations and most academic studies concerning the OMC examine whether national policies moved closer towards its objectives (De la Porte and Pochet 2002a; Zeitlin, Pochet et al. 2005). These analyses often maintain that there are common trends towards OMC objectives in EU member states, at least with regards to the framing of problems and justification of policies (e.g. Zeitlin 2005: 470; López-Santana 2006). Such studies often conclude that the OMC is effective and influences national policy-making. Studies predominantly examining the development of national policies are, however, problematic from a methodological point of view. Firstly, it is unclear which national policy developments should be considered to reflect an OMC 'influence' due to the broadness of the OMC objectives. Secondly, even if national policies appeared to move towards the OMC it is unclear exactly what role the OMC played in this process. It is, for example, possible, that policy change has been triggered solely by internal factors.

Many studies not only analyse policy developments but additionally employ interviews with national policy-makers to explore whether the OMC had an 'influence' on national policies. A comparison of results, however, remains inconclusive. Many policy makers claim that the OMC has not introduced wholly new policies, but merely contributed to the development of existing ones. This is, for example, reported in studies conducted by Jacobsson (2005), Büchs \& Friedrich (2005) and Visser (2005). Some governments even state that their national approaches have shaped the OMC agenda. This has, for instance, occurred in the UK regarding the 'activation' and 'making work pay' agenda (House of Commons 1999: Column 472) and in France regarding the 'social inclusion/exclusion' approach (Erhel, Mandin et al. 2005: 232f.). 
These interviewee statements already indicate that the OMC has to be perceived as a 'twolevel game' in which member state governments pursue their own interests and try to have an effect on the OMC agenda and/or use the OMC in a way that they find politically favourable. Therefore the concept of 'influence' is too simplistic, since it neglects this 'bottom-up' dimension of the OMC.

Due to these problems inherent in the concept of 'influence' in OMC research, I suggest focussing instead on the ways in which policy-actors at the member state level, particularly governments, try to shape the OMC agenda and how they subsequently 'use' the OMC in national policy-making processes. I will discuss this in more detail below. It is first worth briefly examining the theories and explanations within the OMC literature to assess the potential effectiveness and influence of the OMC.

\section{Theorizing the OMC's influence and effectiveness}

Interpretations as to why the OMC could be effective and exert influence on national policy-making have been proposed by authors such as Trubek \& Trubek (2005), Jacobsson (2004) and Hemerijck \& Visser (2001). The list of concepts employed in the literature is varied, comprising policy learning, policy transfer, deliberation, participation, peer pressure, shaming, diffusion and mimicking. Trubek \& Trubek (2005) ordered these different approaches on the axis of top-down versus bottom-up, arguing that these different mechanisms are not necessarily exclusive. Here, I present the concepts of 'naming and shaming', discourse, and 'policy learning,. ${ }^{1}$ I will then argue that the top-down and bottom-up perspectives need to be more radically combined to explain how the OMC works.

\section{Peer pressure and shaming}

Peer pressure and shaming emphasise the 'coercive' and top-down elements of the OMC. These approaches assume that national governments are rational actors who try to avoid 
being 'shamed' or 'blamed' by the EU, other member states or domestic opposition parties for not fulfilling OMC objectives. Theoretically, this could occur because the OMC provides opportunities for shaming and blaming through its benchmarking and evaluation procedures, including quantitative targets and precise timetables that make outcomes measurable and easily comparable (Trubek and Trubek 2005). Since these evaluation processes are reiterated and member states cannot escape from the 'game' played in the EU they have the incentive of avoiding a negative reputation. Such a reputation could have damaging effects in terms of election turnout for the government and could also diminish the trust of economic investors.

There are, however, two preconditions if peer pressure and shaming are to work. Firstly, all or most other member states must take the OMC procedure seriously; otherwise, those complying with the OMC could experience a competitive disadvantage. Secondly, the citizens must be aware of the OMC and concerned about the evaluation results issued by the EU. This can only occur if national policy-makers place the OMC highly on the agenda, discuss it widely and integrate a great number of actors in OMC processes. The media must also report about the OMC extensively. Since empirical analyses demonstrate the OMC's low public and media presence (Umbach 2004; Meyer 2005), it is doubtful that 'shaming' alone will increase the OMC's 'influence' and effectiveness.

\section{Discourse}

In general, discourse approaches emphasise the importance of ideas, language and communication in the construction of the social world, identity building and behaviour. Jacobsson (2004) combined discourse approaches with theories of social interaction and networks to explain the effectiveness of the OMC. Although rejecting a purely structuralist approach, this account still tends to construct the OMC as top-down process. According to this perspective the OMC creates EU-wide discourses, promoting particular values and 
ideas about social policies. Since governments and non-governmental actors at the EU and national levels are integrated into these OMC networks, which meet regularly, the participants are 'socialised' by this discourse. This, in turn, affects national policy-making as governments and non-governmental actors behave according to a 'logic of appropriateness' (March and Olson 2004), adhering to the promoted policy approaches because they think it is the 'right thing to do'.

This discourse approach is useful for understanding some of the aspects surrounding the way in which the OMC works. However, it does not place sufficient emphasis on politics and the strategies of political actors.

\section{Policy learning}

'Policy learning' and 'deliberation' both conceptualise the OMC as a bottom-up process and stress the role of actors. 'Policy learning' assumes that policy makers' perceptions, assumptions and attitudes change voluntarily because they 'rationally' evaluate information and evidence (Hall 1993; Dolowitz and Marsh 1996). The literature identifies different conditions for policy learning. It is more likely to occur if domestic actors are dissatisfied with policy outcomes (Rose 1991: 10f.); if accepted data and theories exist regarding a specific policy problem (Jenkins-Smith and Sabatier 1993: 52); and if a prestigious policy network is in place to provide an incentive for policy-makers to take part in this learning process (ibid: 54). The concept of policy learning within networks can be applied to the OMC (e.g. Kröger 2006). The OMC provides an opportunity for regular meetings and information exchange between member state governments and the European Commission. Regular reports and evaluations contain a pool of 'best practices' from which national actor can learn. In addition, the OMC objectives and targets provide a general framework for interpreting the causes of social problems and developing approaches to tackle them. Ac- 
cording to the policy learning perspective, the OMC provides incentives and valuable information that can lead to voluntary policy learning by the member states.

However, the policy learning approach also bears problems. From an institutionalist perspective (North 1990; Hall and Soskice 2001) one can argue that national institutions tend to hinder voluntary and 'rational' policy learning. This is because policies are deeply embedded in institutional settings and changes considerably diverting from this institutional path are too costly to be adopted - unless there are extraordinary circumstances and 'windows of opportunity'. Since the OMC is not supposed to create such extraordinary circumstances, institutionalists will argue that it is not powerful enough to trigger policy learning if the national and OMC approaches differ too greatly. The emphasis of the OMC's voluntary character in the policy learning and deliberation approach therefore actually points to the limitations of the OMC's effectiveness and 'influence'.

\section{The OMC as a 'two-level game'}

A review of these contrasting approaches demonstrated that all provide useful insights into the puzzle of why a legally non-binding EU governance instrument could possibly exert influence on member state policies and even be effective. According to these approaches, the fact that the OMC is non-binding is an advantage because it would otherwise be impossible to agree upon common objectives at the EU level. The OMC's functioning is then explained either by bottom-up voluntary learning or by top-down socialising effects through repeated interaction, peer review and shaming.

In my view, the top-down and bottom-up perspectives need to be combined in order to comprehend the complexity of the OMC's operation. Firstly it is worth remembering that the OMC is a 'middle way' governance approach. On the one hand, the EU gets involved in European social policy-making but it did not acquire a formal authority for policymaking in the areas covered by the OMC, nor can it steer the process of how OMC objec- 
tives are defined or how member states respond. On the other hand, member states remain formally autonomous in OMC social policy areas, but in fact they become involved in a complex 'two-level game' (Putnam 1988) with the EU.

Putnam's original concept of the 'two-level game' must be slightly adjusted if it is to be applied to the OMC. Putnam employed this concept in the field of international relations in an attempt to develop a theory regarding the conditions of international agreements' successful adoption. He assumed that the outcomes of international negotiations could neither be explained by international nor domestic factors alone, but by a combination of the two. Putnam expressed this theory via the concept of the 'two-level game' in which national policy actors play firstly at the international level (level 1) with the aim of achieving the most favourable outcomes for their country, and secondly at the national arena (level 2) where they must negotiate with a range of powerful policy actors, such as opposition parties and lobbyists. Putnam developed the hypothesis that an international agreement cannot be adopted if the negotiating countries' 'win sets', that is, their sets of agreements that could be approved or ratified domestically, do not overlap. In addition he assumed that international politics can 'reverberate' with domestic politics and therefore trigger a change of public opinion or political actors' attitudes at the national level.

Putnam's concept of the 'two-level game' differs in several respects to the OMC 'twolevel game' that I envisage. Firstly, in contrast to international contracts, OMC objectives and recommendations are not legally binding and do not have to be formally approved by national electorates. Therefore governments cannot oppose the adoption of a specific OMC objective or recommendation by arguing that it could not be ratified at home. However, I propose that they could request that the EU Commission renders OMC objectives, evaluation reports and recommendations more favourable in order to avoid a European backlash at home. This is particularly applicable to countries with Eurosceptic electorates. In addition, if a member state's political system provides opportunities for a broad range of policy 
actors to participate in a public debate on policy development, governments will oppose OMC recommendations that could be used critically by these actors.

Secondly, level 1 in Putnam's two-level game comprises the negotiation partners from other nation states at the international level, often in one-off games. With regards to the OMC, level 1 does not only comprise representatives of other member state governments, but also representatives from the EU Commission. Since the EU Commission is a continuous political actor with whom member states have to negotiate in various policy fields, member state governments must consider the side-effects of OMC negotiations and their long-term interests. It may therefore be difficult for member states to entirely opt out of the OMC. In addition, the OMC is an iterative process in which member state performance is regularly monitored. In order to avoid being 'shamed' member state governments may attempt to influence OMC recommendations and objectives in such a way that enables them to present a favourable image to the EU Commission and their electorates at home. There is a further difference between Putnam's 'two-level game' and my adaptation of this concept. Whilst Putnam focussed on the question of when international agreements can be successfully adopted, I am primarily interested in two aspects; why member state governments agree to certain $\mathrm{OMC}$ objectives and how they subsequently 'use' them in national policy-making.

It is worthwhile to apply the concept of the 'two-level game' to the OMC in order to understand the strategies pursued by different member state governments at the EU and national levels. Putnam's general statements regarding the 'two-level game' also apply to the $\mathrm{OMC}$, such as the realisation that 'It is fruitless to debate whether domestic politics really determine international relations, or the reverse. The answer to that question is clearly "Both, sometimes" (Putnam 1988: 427). The OMC is a combination of top-down and bottom-up processes in which member state governments need to negotiate OMC objectives at the European level and, simultaneously, pursue political strategies 'at home'. They may 
therefore either try to prevent the adoption of OMC objectives and recommendations that could nurture a European backlash at home or agree to OMC objectives because they find them useful as an additional justification for policy change at the national level.

I propose using the notion of 'invited dutifulness' to describe the latter situation in which a member state approves the OMC's introduction and seeks to influence its objectives because it has an interest in 'using' them at home as an additional reform lever. ${ }^{2}$ This is a 'win-win' situation for both sides: member state governments can 'blame' the EU for necessitating policy change despite the fact that the member states themselves are key actors in defining the $\mathrm{OMC}$ objectives. The $\mathrm{EU}$, on the other hand, can claim to make efforts to 'strengthen' social Europe.

The concept of 'invited dutifulness' does not mean that each member state government agrees to the $\mathrm{OMC}$ in the hope of being able to 'blame' the OMC for unpopular policy change. It is also not to say that each member state government is equally successful in defining the OMC agenda or that the EU Commission does not have any power in this 'two-level game'. The argument is rather that the OMC can function according to the logic of 'invited dutifulness' and that the complex and opaque linkages between the EU and the national levels of policy-making weaken member state governments' accountability and pose questions of democratic legitimacy.

The following two sections analyse the OMC policy-making processes and aim to uncover some evidence for the idea that the OMC operates as a 'two-level game'.

\section{Defining the OMC agenda}

An analysis of the way in which the OMC objectives are defined and adopted demonstrates that member state governments play an important and powerful role in this process.

The 'supranational' EU institutions such as the EU Commission and the European Court of Justice are less powerful in the OMC than in policies based on the 'Classical Community 
Method' Scott and Trubek (2002). The Commission has the right to issue proposals on OMC reforms. In addition, it plays an important role in evaluating member state policies in light of the OMC objectives. Overall, it is however less powerful than in the Classical Community Method because of the strong position of member state governments in the OMC process. The European Court of Justice which played an important role in developing EU social law (Falkner, Treib et al. 2005; Leibfried 2005: 248ff.) is not involved with the OMC. Since the OMC objectives are not legally binding the European Court of Justice has no mandate to prove whether member states implemented the objectives or to issue sanctions in cases of non-compliance.

More powerful are the 'intergovernmental' EU institutions in the OMC process. For example, the European Council, although it is not formally an EU institution, has a crucial agenda setting role in the OMC. The Council of the European Union, which represents the member state governments and is the EU's legislative organ, also plays a major role in the OMC. It formally adopts the policy guidelines, quantitative targets and recommendations in the European Employment Strategy. In the OMC in social inclusion and social protection, objectives are merely proposed by the European Council and EU Commission, demonstrating that these OMC strands are even more informal and flexible than the European Employment Strategy.

In contrast to the 'Classical Community Method' the European Parliament does not play a formal role in OMC processes. In the EES, it is a requirement that the European Parliament is consulted about the guidelines (Art. 128, 2 TEC), although it does not possess any rights of co-decision. In the other social policy OMCs, the role of the European Parliament is not formally defined and has thus far only issued opinions regarding the OMC, partially demanding a closer involvement with the OMC (e.g. European Parliament 2002).

Finally, the Employment Committee and the Social Protection Committee play a crucial role in defining the quantitative targets and indicators in the European Employment Strat- 
egy and the $\mathrm{OMC}$ in social inclusion and protection. ${ }^{3}$ Both Committees consist of representatives of all member state governments and two members of the EU Commission. They can invite interest group and NGO representatives as well as academic experts; however no clear rules exist regarding the role of these actors in decision-making processes. The decisions of the Committees are legally non-binding.

Member state governments themselves play an important role in defining the $\mathrm{OMC}$ agenda. This indicates that the OMC is a type of 'two-level game' in which OMC objectives are not merely imposed on the member states but member state governments take into account their political interests at home when negotiating the OMC objectives. The fact that the $\mathrm{OMC}$ is a reiterative process strengthens member state governments' positions within EU Commission negotiations. As the process is regularly repeated, the EU Commission has a vital interest in maintaining a consensual approach and cannot afford to impose OMC objectives on the member states to which they do not agree. This is supported by a piece of research conducted by Jobelius (2003) in which the formulation of $2003 \mathrm{em}-$ ployment guidelines was analysed and concluded that the Commission was not successful in introducing more rigorous quantitative indicators due to opposition by member state governments. The importance of the consensual approach is also demonstrated by the fact that member state governments are asked to widely consult with national social partners and members of the 'civil society' on the OMC objectives to attain their consent before the objectives are adopted.

This section demonstrated that the 'supranational' EU institutions play a relatively insignificant role within OMC processes whilst the 'intergovernmental' institutions and individual member state governments are key in setting the OMC agenda. I will proceed to formulate some hypotheses concerning the different strategies that member state governments may pursue in attempting to define the $\mathrm{OMC}$ agenda and in presenting the $\mathrm{OMC}$ to their national public spheres. 


\section{Member state government strategies}

As indicated above, member state governments will pursue different strategies in the OMC 'two-level game', predominantly dependent upon the reform pressure at home, national political system and public opinion regarding European integration. The hypotheses presented in this section aim to formulate an initial framework upon which subsequent empirical research can be based in an effort to reveal clear patterns of the ways in which different member states use the OMC.

I wish to distinguish three main categories of member state strategy; 'invited dutifulness', 'uploading' and 'ignorance'. In relation to each of these, one must also differentiate between those employed at the $E U$ level in order to influence the OMC agenda and methods of presenting the OMC to national electorates or using it in domestic policy processes. Member state governments do not necessarily openly reveal their strategies pursued on one level to the other. For example, if a member state government readily agreed to an OMC objective at the EU level in the hope that it could support national policy-making, it may not reveal this strategy to its electorate and instead 'blame' the EU for the necessity of introducing policy reforms.

\section{'Invited dutifulness'}

As indicated above, 'invited dutifulness' is a strategy in which member state governments attempt to influence the OMC agenda in such a way that it provides an additional justification for previously planned but unpopular policy reforms at home. 'Invited dutifulness' is particularly likely to occur if the electorate is relatively EU-friendly and if the government (or parts of the government) faces opposition to policy reforms by other key policy players. One example for such a situation occurred in Germany. Here, the 'modernists' in the redgreen government were keen to introduce a far-reaching labour market reform by the 
'Hartz laws' but faced opposition by more traditional social democrats and other key political players. Several of the government-drafted 'Hartz' laws mention the OMC as an additional justification for the reform (Büchs and Friedrich 2005). Visser reports about similar examples of 'invited dutifulness' and concludes that 'the Netherlands actively used the "lessons from Europe" in order to change things at home, but this was always on the basis of existing national political priorities' (2005: 199).

Some authors assume that member state governments will be more inclined to use the OMC in this way if reform pressure is high (De la Porte and Pochet 2002b: 55ff.). So far one finds mixed evidence on that account. One could, for example, draw up the hypothesis that the OMC will have the greatest influence in the new Eastern European member states that are in the process of thoroughly renovating their social policy systems. Some authors indeed report that the new member states have been quite responsive to the OMC (e.g. Plomien 2005; Sleegers 2005). Others, however, argue that lacking resources and considerable differences in the institutional backgrounds are hindrances to implementing the OMC in the new member states (Ingham and Ingham 2003; Galgóczi 2004; Lendvai 2004). One must also take into account that most new member states wish to retain their competitive advantage of lower social standards against the 'old' member states. In other words, if the gap between domestic approaches and the OMC is too large this may also be a hindrance to 'using' the OMC for domestic policy reforms.

A further precondition for 'using' the OMC in the way described above is that the political system provides for 'coordinative' policy discourses (Schmidt 2000) in which the government has to negotiate with a range of policy actors and where justifications for policy change are exchanged in public debates. If this is the case, governments have more incentives to use the $\mathrm{OMC}$ as additional justification for policy change. In addition, actors such as opposition parties, social partners and representatives of regional governments may find 
more opportunities to 'shame' the government by referring to the OMC or use the OMC in order to pressure for policy change.

Finally, for 'invited dutifulness' to occur it is important that there is not a Euro-sceptic electorate. If the electorate is Euro-sceptic, the government may risk unpopularity or triggering a European backlash when referring to the OMC in order to justify policy change.

\section{'Uploading'}

Member state governments may alternatively wish to 'upload' policy approaches already existing at the national level to the OMC agenda in order to demonstrate their sovereignty to electorates and project a refusal to alter policy in accordance with the OMC. This strategy may be pursued for the purpose of minimising adaptation costs and avoiding the unpopularity of too extensive an EU intervention into social policy. Therefore 'uploading' will primarily be pursued by member states with a relatively Eurosceptic electorate, such as the UK or Sweden. Indeed, several empirical studies report that the British, Swedish, and Danish governments were successful in 'uploading' their policy approaches to the OMC agenda (Ferrera and Sacchi 2005: 142). Some of these member state governments were also eager to demonstrate their influential role in shaping the OMC agenda to their electorates (Erhel, Mandin et al. 2005; Jacobsson 2005; Armstrong 2006). This strategy may provide the double function of demonstrating the superiority of member states' national policy approaches and highlighting their powerful position within the EU arena. This is hoped to prevent a European backlash at home.

A subcategory within the 'uploading' strategy can be identified as the influencing of individual aspects of the OMC agenda in order to prevent negative publicity in evaluation procedures. This can be illustrated by the fact that the EU Commission included job counselling into its definition of 'measures of active labour market policy'. This was demanded by the UK government, who strongly opposed the Commission's view that the UK did not 
comply with the objective of providing a measure of active labour market policy for young people after six months of unemployment at the latest (House of Commons 2003: para 9.8). Due to this intervention, the UK is now the only EU country reported to be fully complying with these activation objectives (European Commission 2006: 56ff.).

In some cases, the strategy of uploading will be strongly related to a member state government publicly refusing or denying that the OMC informed domestic policy-making in any way. This strategy can again be illustrated by taking the UK as an example. Here, the government publicly refused to strengthen 'social partnership' at the national level (The Scottish Parliament and European and External Relations Committee 2003) and to provide earlier access to the New Deal programmes (United Kingdom 2001: 8f.). Interestingly, the UK government recently introduced several pilot projects in which earlier access to the New Deal programmes is now available (Clasen 2005: 200). However, these changes were not publicly justified by references to the OMC.

In summary, member state governments may attempt to 'upload' national policy approaches to the OMC agenda if they are powerful players at the EU level, internal reform pressure is low and their electorates are Euro-sceptic. In countries with Euro-sceptic electorates and political systems that do not provide for 'coordinative discourses' but rely upon a relatively centralised style of political communication, member state governments will also tend to present themselves to their public as sovereign governments that successfully shape the OMC agenda but are not influenced by the OMC themselves.

'Ignorance'

A third strategy can be identified to be ignorance of the OMC, for example, inactivity in shaping the OMC agenda or ignorance of the OMC within domestic political discourse. Inactivity in defining the $\mathrm{OMC}$ agenda is possible since member state governments are aware that $\mathrm{OMC}$ objectives are not legally binding, their national parliaments are not 
obliged to transpose them into national law and the EU cannot impose any formal sanctions if the objectives are not achieved. It therefore poses no political risk for governments to agree to ambitious objectives or policy approaches that are quite distinct from those existing 'at home'.

Member state governments may pursue this strategy if they have no bargaining power at the EU level or their domestic policy approaches remain so detached from the general OMC agenda that they could not realistically conform to its objectives even if they were slightly adjusted. Governments can only ignore the OMC within domestic policy discourse if there is little open public discussion and non-governmental actors do not have great opportunities or incentives for using the OMC to 'shame' the government.

To summarise, the OMC is not a purely top-down strategy and is therefore not powerful enough to be the primary cause of the introduction of new policies at the member state level. However, it is neither a purely bottom-up process in which member states are entirely free to shape OMC objectives or neglect the OMC within domestic policy-making. Instead the OMC can be perceived as a 'two-level game' in which member state governments seek to influence OMC objectives in a manner that is beneficial to them in their national policy 'games'. In addition, governments do not have complete control over the way in which the OMC is used by other domestic policy actors and cannot completely avoid being 'shamed' if performance is poor.

Thus far empirical research suggests that 'invited dutifulness' and 'uploading' are the two strategies predominantly pursued by member state governments (De la Porte and Pochet 2002a; Zeitlin, Pochet et al. 2005). Since the OMC 'two-level game' can be played as 'invited dutifulness', it can be argued that the OMC has the potential to serve as an additional justification for domestic policy reform and thus function as a catalyst for policy develop- 
ment in some member states. In the conclusion I will discuss the consequences that this mode of 'two-level game' has for political transparency and accountability.

\section{Conclusion}

Here I will review the arguments outlined within this paper and consider their consequences for the accountability of national governments and legitimacy of the OMC. The paper argued that it is more useful to examine the OMC's role in national policy-making than to apply a simplistic model of 'influence' on national social policies. The main reason for this lies in the methodological problems involved in empirically identifying the OMC's impact on national policies. Since the OMC is not legally binding, governments and parliaments do not have to formally transpose its objectives into national programmes and possible 'implementation' processes are informal and transparent. References to the OMC in the policy-making process can, though do not necessarily, reflect a 'real' influence of the OMC; and vice versa, an 'influence' of the OMC on national policy-making can, but is not necessarily, reflected by explicit references to the OMC. In addition, if policies adhere more closely to the OMC after its introduction, this is not a sufficient indicator of its influence as other external and internal forces may have contributed to this change.

Existing explanations of the OMC's potential effectiveness provide some insight into possible motives and mechanisms of its potential influence on national policies. However, they do not analyse the OMCs role in policy-making processes or the conditions affecting whether, and if so, how, domestic policy actors 'use' the OMC in national policy-making. Empirical analyses should focus on the latter question since one can assume that the OMC provides new communication strategies for both governmental and non-governmental national actors. Governments can strategically 'use' the OMC to reframe policy approaches and justify possibly unpopular policy reforms. Non-governmental policy actors or opposition parties can refer to the $\mathrm{OMC}$ in order to put pressure on the government to move 
closer to OMC objectives - whether they are successful or not is, however, determined by other factors such as domestic power relationships.

Overall, the OMC is a 'two-level game' in which governments, but also non-governmental actors, can try to lobby the EU Commission and influence the OMC agenda in order to provide themselves with an addition reform lever 'at home'. I termed this strategy 'invited dutifulness'. Since the OMC is not legally binding, the member state governments are not accountable to the EU in its implementation. This provides the opportunity for national governments to 'use' the OMC selectively in the policy-making process. Empirical research demonstrates that this is the case in several member states. For example, the German government referred to the OMC in a series of labour market policy draft laws that strengthened the 'activation' and 'making work pay' agenda. Here the OMC was alternatively used as an additional justification for an unpopular policy change.

The OMC can also be used selectively in the mode of 'uploading'. For instance, the French and the British governments publicly claimed that they were able to 'upload' their policy approaches to the OMC agenda. These claims imply that these policy approaches were so successful that they were approved by the EU as a blueprint for a 'European' model thus providing an additional justification for the domestic approach.

The way in which the OMC is used by governments poses problems in terms of accountability and democratic legitimacy. Overall, one can argue that the OMC strengthens the role of national governments vis-à-vis national parliaments. National governments as well as other non-governmental actors play a crucial role in defining the OMC objectives. The processes in which the OMC objectives are formulated are, however, very opaque. It is not clear to electorates exactly who is participating in these processes or which actors are successful in influencing the OMC agenda. Member state electorates cannot, therefore, hold the actors responsible for the content of the OMC objectives accountable. Neither the European nor national parliaments are involved in formulating the OMC objectives. The 
objectives therefore lack any input-legitimacy. All this is problematic if national governments subsequently 'use' the OMC in political discourses to justify existing policies by 'credit claiming' or defend planned changes by 'blaming' the EU. Overall, it can be maintained that the process of domestic agenda setting in social policy is deparliamentarised. General perspectives on social problems and potential policy solutions are increasingly defined through complex and opaque policy networks external to parliaments.

One could argue that a trade-off exists between accountability provisions and the effectiveness of policies, as strict accountability provisions may hamper the efficiency of policy-making and subsequently the effectiveness of policies. This poses the question of whether or not the weak provisions for accountability and democratic legitimacy in the OMC increased its effectiveness. If this question is measured against the hope and claim from many OMC optimists that it could strengthen 'social Europe' the answer will be in the negative. The OMC has not established any social rights or binding provisions which could bring the EU's social and economic objectives into balance. Thus far the OMC has primarily been used by national governments to implement a social policy agenda that is compatible with a programme prioritising economic growth and efficiency, and strict budgetary policies. Furthermore, most of the OMC's own objectives have not been achieved, such as the reduction of poverty and social inequality which have both stagnated since the late 1990s and even risen during the last year. ${ }^{4}$

To conclude, the $\mathrm{OMC}$ is able to strengthen power positions in national policy-making processes through providing extra arguments to governments in justifying existing policies or policy change. However, this role of the OMC in national policy-making weakens the accountability of national governments and must be questioned from the perspective of input-legitimacy. This insufficient accountability and legitimacy have, however, not contributed to an effective EU social policy strategy. The OMC is therefore insufficient on accounts of both legitimacy and effectiveness. 


\section{Notes}

1 The concept of diffusion is also relatively famous in the OMC literature but I omit it here because of its strong functionalistic connotations. This functionalistic orientation is not suitable if one seeks to focus on actors and policy-making processes.

2 I adopted this term from Visser who used the German term 'eingeladene Gehorsamkeit' to describe how the Dutch government 'used' the OMC in national policy-making (cf Visser 2005: 199).

3 Both Committees were formally established in 2000, the Employment Committee has, however, several forerunners and has a Treaty basis since the Amsterdam Treaty.

$4 \quad$ See Eurostat data on http://epp.eurostat.ec.europa.eu/, download 3 July 2006.

\section{References}

Armstrong, K. A. (2006) 'The 'Europeanisation' of Social Exclusion: British Adaptation to EU Co-ordination', British Journal of Politics and International Relations 8 (1): 79-100.

Büchs, M. and Friedrich, D. (2005) 'Surface Integration. The National Action Plans for employment and social inclusion in Germany', in Zeitlin, J., Pochet, P. and Magnusson, L., The Open Method of Co-ordination in Action. The European Employment and Social Inclusion Strategies, Brussels et al.: Peter Lang, 249-285.

Chalmers, D. and Lodge, M. (2003) The Open Method of Co-ordination and the European Welfare State, Discussion Paper No 11, June 2003, ESRC Centre for Analysis of Risk and Regulation, London School of Economics and Political Science.

Clasen, J. (2005) Reforming European Welfare States. Germany and the United Kingdom compared, Oxford: Oxford University Press.

De la Porte, C. and Pochet, P. (2002a) Building Social Europe Through the Open Method of Coordination, Brussels: Peter Lang.

De la Porte, C. and Pochet, P. (2002b) 'Supple coordination at EU level and the key actors' involvement', in De la Porte, C. and Pochet, P., Building Social Europe through the Open Method of Co-Ordination, Brussels: P.I.E-Peter Lang, 27-68.

Dolowitz, D. and Marsh, D. (1996) 'Who learns what from whom: a review of the policy transfer literature', Political Studies XLIV: 343-357.

Erhel, C., Mandin, L., et al. (2005) 'The leverage effect: the Open Method of Coordination in France', in Zeitlin, J., Pochet, P. and Magnusson, L., The Open Method of Coordination in Action: The European Employment and Social Inclusion Strategies, Brussels et al.: Peter Lang, 217-247. 
European Commission (2006) Indicators for monitoring the Employment Guidelines 2005 compendium, European Commission, available under: http://ec.europa.eu/employment_social/employment_strategy/pdf/compendium ma y 2006 en.pdf, accessed 21 June 2006.

European Council (2000a) Presidency Conclusions, Nice European Council, 7, 8 and 9 December 2000.

European Council (2000b) Presidency Conclusions, Lisbon European Council, 23 and 24 March 2000.

European Parliament (2002) Guidelines on employment. European Parliament resolution on the communication from the Commission on taking stock of five years of the European Employment Strategy, Committee on Employment and Social Affairs, P5_TA(2002)0442, 25.09.2002.

Falkner, G., Treib, O., et al. (2005) Complying with Europe? Theory and practice of minimum harmonisation and soft law in the multilevel system, Cambridge: Cambridge University Press.

Ferrera, M. and Rhodes, M. (2000) 'Building a sustainable welfare state', West European Politics special issue: $257-282$.

Ferrera, M. and Sacchi, S. (2005) 'The Open Method of Coordination and national institutional capabilities. The Italian Experience', in Zeitlin, J., Pochet, P. and Magnusson, L., The Open Method of Co-ordination in Action: The European Employment and Social Inclusion Strategies, Brussels et al.: Peter Lang, 137-172.

Galgóczi, B. (2004) 'The implementation of the EES in the context of the accession and candidate countries', in Galgoczi, B., Lafoucriere, C. and Magnusson, Lars, The enlargement of social Europe; The role of social partners in the European Employment Strategy, Brussels: European Trade Union Institute (ETUI), 77-94.

Hall, P. A. (1993) 'Policy paradigms, social learning, and the state: The case of economic policy making in Britain', Comparative Politics 25 (3): 275-296.

Hall, P. A. and Soskice, D. (2001) Varieties of Capitalism. The Institutional Foundations of Comparative Advantage, Oxford, New York: Oxford University Press.

Hemerijck, A. and Visser, J. (2001) Learning and Mimicking: How European Welfare States Reform (manuscript), University of Leyden / University of Amsterdam.

House of Commons (1999) Commons Hansard, Employment Harmonisation (EU), A. Smith, 29.04.1999, Column 472.

House of Commons (2003) Joint Employment Report, Select Committee on European Scrutiny, Sixth Report, Section 9, Session 2002-03, HC 63-vi, 15.01.2003, London.

Ingham, M. and Ingham, H. (2003) 'Enlargement and the European Employment Strategy: turbulent times ahead?' Industrial Relations Journal 34 (5): 379-395.

Jacobsson, K. (2004) 'Soft regulation and the subtle transformation of states: The case of EU employment policy', Journal of European Social Policy 14 (4): 355-370.

Jacobsson, K. (2005) 'Trying to reform the 'best pupils in the class'? The Open Method of Coordination in Sweden and Denmark', in Zeitlin, J., Pochet, P. and Magnusson, L., The Open Method of Co-ordination in Action: The European Employment and Social Inclusion Strategies, Brussels et al.: Peter Lang, 107-136.

Jacquot, S. and Woll, C. (2003) 'Usage of European Integration - Europeanisation from a sociological perspective', European Integration Online Paper 7 (12): available under: http://eiop.or.at/eiop/texte/2003-2012a.htm, accessed 2021 August 2006.

Jenkins-Smith, H. C. and Sabatier, P. A. (1993) 'The dynamics of policy-oriented learning', in Sabatier, P. A. and Jenkins-Smith, H. C., Policy Change and Learning. An Advocacy Coalition Approach, Boulder: Westview Press, 41-56.

Jobelius, S. (2003) Who formulates the European Employment Guidelines? The OMC between deliberation and power games, Paper presented to the Annual Conference of 
the ESPA net 'Changing European Societies - The Role for Social Policy', 13-15 November 2003, Copenhagen.

Kröger, S. (2006) 'When learning hits politics or: Social policy coordination left to the adinistrations and the NGOs?' European Integration Online Papers available under http://eiop.or.at/eiop/index.php/eiop/article/viewFile/2006 003a/18, accessed 17 June 2006.

Leibfried, S. (2005) 'Social Policy', in Wallace, H., Wallace, W. and Pollack, M. A., Policy Making in the European Union, fifth edition, Oxford: Oxford University Pres, 243278.

Lendvai, N. (2004) The indigenisation of social inclusion policy in post-communist Europe and its implication for EU social policy after enlargement, Paper for the secon ESPAnet conference, Oxford, September 2004.

López-Santana, M. (2006) 'The domestic implications of European soft law: framing and transmitting change in employment policy', Journal of European Public Policy 13 (4): 481-499.

March, J. G. and Olson, J. P. (2004) The logic of appropriateness, ARENA working paper WP 04/09, available under: http://www.arena.uio.no/publications/wp04 9.pdf\#search=\%22March\%20logic\%2 0appropriateness\%22, accessed 08 September 2006.

Meyer, C. (2005) 'The Europeanization of Media Discourse: A study of quality press coverage of economic policy co-ordination since Amsterdam', Journal of Common Market Studies 43 (1): 121-148.

North, D. C. (1990) Institutions, institutional change and economic performance, Cambridge: Cambridge University Press.

Plomien, A. (2005) Half Full or Half Empty? Labour market policy making in post socialist poland, EUSA Ninth Biennial International Conference Austin, Texas, March31-April 2, 2005.

Putnam, R. D. (1988) 'Diplomacy and domestic politics: the logic of two-level games', International Organization 42 (3): 427-460.

Rose, R. (1991) 'What is lesson-drawing?' Journal of Public Policy 11 (1): 3-30.

Schmidt, V. A. (2000) 'Values and discourse in the politics of adjustment', in Scharpf, F. W. and Schmidt, V. A., Welfare and Work in the Open Economy. Vol. I: From Vulnerability to Competitiveness, Oxford: Oxford University Press, 229-309.

Scott, J. and Trubek, D., M. (2002) 'Mind the gap: Law and new approaches to governance in the European Union', European Law Journal 8 (1): 1-18.

Sleegers, P. J. (2005) Changing Welfare States. An institutional explanation for the susceptibility to policy learning by means of the OMC social inclusion. The cases Czech Republic, Hungary and Latvia, Master's Thesis, University of Twente, Enschede.

The Scottish Parliament and European and External Relations Committee (2003) Report on Europe's Employment Strategy and Corporate Social Responsibility: An inquiry into the Scottish model, Volume 2 - evidence, Edinburgh.

Trubek, D. and Trubek, L. (2005) 'The Open Method of Coordination and the debate over 'hard' and 'soft' law', in Zeitlin, J., Pochet, P. and Magnusson, L., The Open Method of Co-ordination in Action: The European Employment and Social Inclusion Strategies, Brussels et al.: Peter Lang, 83-103.

Umbach, G. (2004) Employment Policies in Germany and the United Kingdom - The Impact of Europeanisation, Political Science Report prepared for The Anglo German Foundation for the Stud of Industrial Society, London/Cologne, available under: http://www.agf.org.uk/pubs/pdfs/1359web.pdf, accessed 11 September 2006. 
United Kingdom (2001) UK Employment Action Plan 2001, available under:

http://ec.europa.eu/employment_social/employment_strategy/national_en.htm, accessed 27 July 2006.

Visser, J. (2005) 'The Open Method of Coordination as selective amplifier for national strategies of reform. What the Netherlands want to learn from Europe', in Zeitlin, J., Pochet, P. and Magnusson, L., The Open Method of Co-ordination in Action: The European Employment and Social Inclusion Strategies, Brussels et al.: Peter Lang, 173-215.

Wallace, H. (2005) 'An institutional anatomy and five policy modes', in Wallace, H., Wallace, W. and Pollack, M. A., Policy Making in the European Union, fifth edition, Oxford: Oxford University Pres, 49-90.

Zeitlin, J. (2005) 'The Open Method of Coordination in action: theoretical promise, empirical realities, reform strategy', in Zeitlin, J., Pochet, P. and Magnusson, L., The Open Method of Co-ordination in Action: The European Employment and Social Inclusion Strategies, Brussels et al.: Peter Lang, 447-503.

Zeitlin, J., Pochet, P., et al. (2005) The Open Method of Coordination in Action: The European Employment and Social Inclusion Strategies, Brussels et al.: Peter Lang. 